\title{
THE EFFICIENCY OF HIGH-FREQUENCY ENDOVENOUS WELDING FOR THE SURGICAL TREATMENT OF ACUTE ASCENDING THROMBOPHLEBITIS OF THE GREAT SAPHENOUS VEIN
}

\section{EFEKTYWNOŚĆ WEWNĄTRZNACZYNIOWEGO ZGRZEWANIA DIELEKTRYCZNEGO W CHIRURGICZNYM LECZENIU OSTREGO WSTĘPUJACEGO ZAKRZEPOWEGO ZAPALENIA ŻYŁY ODPISZCZELOWEJ}

\author{
Anastasiia Glagolieva ${ }^{1(\mathrm{D}, \mathrm{E}, \mathrm{F})}$, Roman Gerashchenko ${ }^{1(\mathrm{~A}, \mathrm{~B}, \mathrm{E})}$, Andrii Kurmanskyi ${ }^{1(\mathrm{C}, \mathrm{D}, \mathrm{F})}$, \\ Vladyslav Gorbovets $^{1(\mathrm{~A}, \mathrm{E}, \mathrm{F})}$, Valentyn Khodos $^{1(\mathrm{D}, \mathrm{E})}$, Sergii Savolyuk ${ }^{1(\mathrm{E})}$
}

${ }^{1}$ The P.L. Shupyk National Medical Academy of Postgraduate Education, Kyiv, Ukraine

Authors' contribution Wkład autorów:

A. Study design/planning zaplanowanie badań B. Data collection/entry zebranie danych C. Data analysis/statistics dane - analiza i statystyki D. Data interpretation interpretacja danych E. Preparation of manuscript przygotowanie artykułu F. Literature analysis/search wyszukiwanie $i$ analiza literatury G. Funds collection zebranie funduszy
Tables: 0

Figures: 1

References: 21

Submitted: 2020 Jan 15

Accepted: 2020 March 24

\section{Summary}

Background. Acute ascending thrombophlebitis of the great saphenous vein (GSV) is an adverse complication of varicose veins of the lower extremities. Conventional surgical treatment comprises traumatic removal of thrombotic vein trunk by means of a Babcock probe. Endovascular welding is a promising, minimally invasive treatment for varicose veins, which may also be applied for hemodynamic correction of impaired venous blood flow of the lower extremities in urgent conditions.

Material and methods. Thirty-six patients diagnosed with acute ascending thrombophlebitis type III and IV, stage C2-C6 (CEAP) were treated using an EK300M electric welding device (LLC Svarmed, Ukraine) for high-frequency electric welding of living tissues guided by endovenous probes. Changes in the treated venous trunks were analyzed by ultrasound, and quality of life before and after surgical treatment was evaluated using a chronic insufficiency venous international questionnaire (CIVIQ).

Results. Twelve months after high-frequency endovenous electric welding 33 patients (91.41\%) had complete occlusion and fibrous transformation in areas of the thrombus segments of the GSV. Two patients (5.54\%) had hemodynamically insignificant partial recanalization of separate vein segments, and one patient (2.77\%) had complete recanalization of the GSV trunk. Conclusions. Endoscopic welding is an effective, minimally traumatic alternative method for the surgical treatment of acute ascending thrombophlebitis III and VI type of the GSV.

Keywords: venous insufficiency, thrombophlebitis, varicose veins, quality of life

\section{Streszczenie}

Wprowadzenie. Ostre wstęujące zakrzepowe zapalenie żyły odpiszczelowej (great saphenous vein - GSV) jest poważnym powikłaniem występowania żylaków kończyn dolnych. Konwencjonalne metody leczenia chirurgicznego polegają na inwazyjnym usunięciu pnia żyły zakrzepowej za pomoca sondy Babocka. Zgrzewanie wewnattrznaczyniowe jest obiecująca, minimalnie inwazyjną metodą leczenia żylaków, która może być stosowana do poprawy hemodynamiki osłabionego przepływu krwi żylnej w kończynach dolnych w nagłych przypadkach.

Materiał i metody. Zbadano i przeanalizowano rezultaty leczenia 36 pacjentów ze zdiagnozowanym ostrym wstępującym zakrzepowym zapaleniem żył typu III i IV w fazie C2C6 (CEAP). Leczenie przeprowadzono przy użyciu urządzenia do dielektrycznego zgrzewania tkanek żywych EK300M (LLC Svarmed, Ukraina) i sond dożylnych. Zmiany w leczonych pniach żył oceniono przy pomocy USG, a jakość życia przed leczeniem chirurgicznym i po nim oceniono za pomocą kwestionariusza klinicznego CIVIQ (międzynarodowy kwestionariusz dotyczący przewlekłej niewydolności żylnej).

Wyniki. Rok po przeprowadzeniu dielektrycznego zgrzewania wewnątrznaczyniowego 33 pacjentów $(91,41 \%)$ wykazało pełną okluzję i transformację włókien w obrębie segmentu zakrzepu GSV. Dwóch pacjentów (5,54\%) doznało częściowej rekanalizacji odrębnych segmentów żyły, a jeden $(2,77 \%)$ - całkowitej rekanalizacji pnia GSV.

Wnioski. Zgrzewanie endoskopowe jest efektywną alternatywą dla chirurgicznych metod leczenia zakrzepowego zapalenia żyły odpiszczelowej typu III i IV. Cechuje je niski stopień inwazyjności.

Słowa kluczowe: niewydolność żylna, zakrzepowe zapalenie żył, żylaki kończyn dolnych, jakość życia

Glagolieva A, Gerashchenko R, Kurmanskyi A, Gorbovets V, Khodos V, Savolyuk S. The efficiency of high-frequency endovenous welding for the surgical treatment of acute ascending thrombophlebitis of the great saphenous vein. Health Prob Civil. 2020; 14(2): 94-99. https://doi.org/10.5114/hpc.2020.94100

Address for correspondence / Adres korespondencyjny: Anastasiia Glagolieva, The P.L. Shupyk National Medical Academy of Postgraduate Education, Dorohozhytska St. 9, 04112 Kyiv, Ukraine, e-mail: nglagoleva90@gmail.com, phone:+38044 20548 69. ORCID: Anastasiia Glagolieva https://orcid.org/0000-0003-1256-7277, Roman Gerashchenko https://orcid.org/0000-0001-6582-9934, Vladyslav Gorbovets https://orcid.org/0000-0003-1744-9544,

Valentyn Khodos https://orcid.org/0000-0003-0150-3868, Sergii Savolyuk https://orcid.org/0000-0001-5406-8228

Copyright: (C) Pope John Paul II State School of Higher Education in Biała Podlaska, Anastasiia Glagolieva, Roman Gerashchenko, Andrii Kurmanskyi, Vladyslav Gorbovets, Valentyn Khodos, Sergii Savolyuk. This is an Open Access journal, all articles are distributed under the terms of the Creative Commons Attribution-NonCommercial-ShareAlike 4.0 International (CC BY-NC-SA 4.0) License (http://creativecommons.org/licenses/by-nc-sa/4.0/), allowing third parties to copy and redistribute the material in any medium or format and to remix, transform, and build upon the material, provided the original work is properly cited and states its license. 


\section{Introduction}

Acute ascending thrombophlebitis of the superficial veins (AATSV) is one of the most common pathologies arising from varicose veins in the lower extremities [1]. The condition is typically associated with pregnancy, prolonged immobilization of the limb, vasculitis, cancer, hormone therapy, obesity, thrombophilia and protein $\mathrm{S}$ deficiency [2]. The prevalence of lower extremity AATSV in the general population ranges from 3-11\%, but it develops more frequently in older women (50-70\%) [3]. Of all AATSV cases, $60-80 \%$ affect the great saphenous vein system and in 5-10\% of patients the condition features bilaterally [3-5]. According to consensus of the Central European Vascular Forum in 2014, recommended treatment for thrombophlebitis of the great or small saphenous vein (GSV or SSV) systems, which has been verified by ultrasound and which involves a blood clot of more than $5 \mathrm{~cm}$ in length, entails anticoagulant therapy with either Fondaparinux $2.5 \mathrm{mg}$ for at least 45 days or low molecular weight heparins (LMWH) for a duration of 4 weeks [6]. However, a series of randomized studies, reviewed in the Cochrane Database indicate that conventional surgical treatment of localized lower extremity vein thrombophlebitis may prevent the spread of thrombus to the sapheno-femoral junction [6, 7]. Benefits of surgical intervention are therefore believed to include reduction of symptoms and lowering of the risk of pulmonary embolism by preventing the progression of blood clots into the deep venous system [8,9].

Currently, standard surgical treatment of advanced AATSV involves removal of the entire thrombosed trunk of the GSV using a Babcock stripper, or multiple affected sites with separate incisions [10-14]. However, a high risk of complications, localized trauma, as well as the associated physical, social and psychological rehabilitation time provide impetus for the development and implementation of an alternative, minimally-invasive method of surgical treatment for AATSV of the GSV. High-frequency electric welding which has been modified for implementation in living tissues may be adapted to provide endovenous obliteration of the thrombotic trunk of the GSV [15].

High-frequency electric welding of living endovenous tissue, referred to as endovenous electric welding (EVEW), involves delivery of a high-frequency electric current to the thrombotic masses and vessel wall by endovenous catheter, heating these structures to above $90{ }^{\circ} \mathrm{C}$. The applied current, closed by an electric arc, induces a controlled spasm of the venous wall and denaturation of intracellular proteins of the thrombotic masses and of the venous wall, promoting occlusion, fibrotic transformation and vein ablation $[16,17]$.

Patients with chronic venous insufficiency of the lower extremities, and particularly those who develop AATSV, may experience a marked decline in quality of life (QoL) [18]. Most questionnaires (including SF-36, AVVQ and EQ-5D) do not allow thorough identification of the impact of varicose vein pathologies, such as superficial thrombophlebitis of the lower extremities, on different aspects of QoL, nor do they allow effective comparisons as a function of intensity of this impact at different time intervals [19]. A validation study employing the Dutch VEnous INsufficiency Epidemiological and Economic Studies (VEINES) questionnaire, including Quality of Life and Symptoms subscales (VEINES-QoL/Sym), was found to be unstable in factor structure regarding the disease etiopathology and course [18]. Currently, the most optimal qualitative assessment of QoL may be achieved by means of the CIVIQ questionnaire, which comprises 20 questions relevant to psychological, physical, and social functioning, as well as pain syndrome [19]. This questionnaire has been validated across these areas, with Cronbach's alpha exceeding 0.82 for 3 of the 4 factors [19]. The standardized mean response and effect size in the aforementioned CIVIQ study also demonstrated sensitivity of the questionnaire for detection of minimal changes (>0.80) [19]. In this study, clinical efficiency was evaluated in patients with AATSV GSV and changes in QoL criteria were evaluated using the CIVIQ questionnaire. Both types of assessments were implemented at predetermined time intervals before and after EVEW treatment [20,21].

The aim of this study was to evaluate the effectiveness of the EVEW method in patients with AATSV, according to clinical criteria, instrumental parameters and QoL indicators as assessed by the CIVIQ questionnaire.

\section{Material and methods}

Over a period from 2018 to 2019, 36 patients with AATSV were treated using the EVEW method at the surgical departments of the City Clinical Hospital No. 8 of Kyiv, Ukraine. The age of patients participating in the study ranged from 19 to 78 years (mean age $51.28 \pm 2.63$ years). There were 11 men (30.47\%) and 25 women (69.53\%). All participating patients diagnosed with AATSV also presented with varicose veins of the lower extremities. All patients were admitted to the surgical departments on an emergency basis. According to the international Clinical Etiological Anatomical Pathophysiological (CEAP) classification, AATSV classified as stage C2 was observed in 5 patients (14.00\%), stage C3 in 13 patients (36.01\%), stage C4 in 7 patients (19.40\%), stage C5 in 8 patients $(22.20 \%)$ and stage C6 in $3(8.31 \%)$. The duration of the disease in patients at the time of admission to 
the hospital varied. 8 patients (22.20\%) experienced symptoms for up to 3 days, 21 patients (58.20\%) for up to 7 days and 7 patients (19.40\%) for up to 14 days prior to admission. All patients reported pain in the thrombus vein, hyperemia, hyperpigmentation of the skin over the thrombosed veins, paravasal edema and difficulty moving limbs. The severity of clinical manifestations of AATSV at time of admission correlated with the time elapsed since onset of disease symptoms. All patients underwent duplex ultrasound scanning using a TOSHIBA Nemio XG device (Japan) equipped with a convex sensor with an operating frequency of 3.5-5 MHz and a linear sensor with a range of 7.5-12 MHz. The ultrasound was used to observe the condition of the walls and the lumen of the veins, detect the presence of thrombotic masses, characterize the thrombus as occlusive or flotation, determine occlusion limits, evaluate the degree of organization of the thrombusand extent of venous blood flow in the area of thrombotic masses and, finally, establish the presence of pathological vertical and horizontal reflux. Ultrasound was strictly applied to monitor the deep veins of both lower extremities for presence of a thrombotic process in their system.

Indications for EVEW treatment were the presence of thrombotic masses in the sapheno-femoral junction $(\mathrm{SFJ})$, limited $(1.5-2 \mathrm{~cm})$ spread of the thrombus to the femoral vein and progression of the disease on the background of conservative treatment. Surgical treatment strategies were constructed according to the outcomes of ultrasound-based evaluations.

The instrumentation assembly for EVEW includes a multifunctional generator of high-frequency electric current for welding of live tissues, presently the EK300M welding device (LLC Svarmed, Ukraine), and endovenous electrowelding catheters (EC) of various calibers and configurations. All procedures were performed under local infiltration anesthesia. As a current source, the EK300M welding device produces a lower final heating temperature compared with conventional radio-frequency ablation generators, due to differences in hardware and software, resulting in lower thermal injury to surrounding tissues. The endovenous handpiece of this generator includes two isolated electrodes with different polarities, fixed to each other in the form of an ellipsoid, with diagonals of linear dimensions set at an optimal ratio of 1:2 $\pm 10 \%$, which increases the contact area between the handpiece and venous wall. Handpiece calibers can vary from 4 to $7.5 \mathrm{~mm}$. The handpiece is connected to a flexible tube $40 \mathrm{~cm}$ to $100 \mathrm{~cm}$ long with a diameter of $1.7 \mathrm{~mm}$ to $2.7 \mathrm{~mm}$. The tube is made of polymer material (a combination of polyamide and polyurethane) which is formulated to ensure optimal flexibility and rigidity ratio to allow appropriate movement of the tool in the lumen of the vein.

The EVEW of the thrombus trunk was performed according to the following procedure: typical access to SFJ by Brunner U. than a direct thrombectomy, high ligation of the ostium and tributaries of GSV (crossectomy) by Bergan were performed. After a crossectomy, EC was injected into the lumen of the thrombosed GSV trunk in the retrograde direction. Current was applied at 50\% power and was manually controlled via control pedal by an operator. The ultrasound sensor, positioned above the working part of the EC in the longitudinal plane of the scan, in B-mode enabled real-time guidance for movement and positioning of the EC, as well as observation of the efficacy of EVEW (sharp spasm, wall thickening and vein occlusion). The process duration for welding a segment of the vein $5 \mathrm{~cm}$ in length was 15 seconds. Subsequently, the operator manually relocated the EC to another target area of the GSV. This process was repeated along the full length of the thrombosed trunk. The relocation of the electric probe was performed discretely with a step ranging from $6 \mathrm{~mm}$ to $5 \mathrm{~cm}$, depending on the caliber and configuration of the working part of the EC. At the completion of EVEW, the vein was welded by means of an electrowelding bipolar clamp, followed by suturing of the surgical wounds. Additional stages of surgery were performed if necessary, including miniflebectomy or dissection of perforated veins. Elastic limb compression was applied post-surgery using compression stockings.

All patients were able to leave the operating room unassisted. From 2-3 days, patients were able to return to normal activities and returned to work from 10 days after surgery. During hospitalization, patients were treated with oral medication (nimesulide, ibuprofene) and no administration of narcotic analgesics or antibiotics was necessary. Elastic compression was applied continuously for the first 7 days, after which compression was maintained during day time only up to 30 days after surgery.

QoL indicators were evaluated directly on admission and evaluation was repeated at 2 days, 7 days, 3 months, 6 months and 12 months after EVEW treatment. Using the CIVIQ (chronic insufficiency venous international questions) clinical questionnaire, questions associated with the four QoL indicators (pain, physical, social and psychological functioning) were grouped into blocks representing each of these criteria and were scored on a 5-point scale. According to the scale used, 1 point reflected no complaints, 2 points reflected light or infrequent complaints, 3 points reflected moderate or frequent complaints, 4 points reflected strong or very frequent complaints and 5 points reflected very strong or constant complaints over the 4 weeks prior to evaluation [17]. The sum of points for the four blocks of questions, each block representing on QoL indicator, differed depending on the number of questions in the block and the totals were therefore transferred to a relative scale with values 
ranging from 0 to $100 \%$ using the following formula: (a-b) / (c-b) * 100\% = X, where X is the QoL index; a is the actual sum of points; $b$ is theoretically the minimum score and $c$ is theoretically the maximum score.

Statistical processing of the results was performed using Statistica statistical analysis software. The processing of the obtained data was performed using nonparametric methods. Difference $\left(\mathrm{T}_{\mathrm{RIZ}}\right)$ and rank difference number $\left(\mathrm{TRN}_{\mathrm{RIZ}}\right)$ were calculated. The significance of differences between the results of the survey before treatment and at previously-described post-surgical intervals was evaluated using the nonparametric Wilcoxon T test. Differences were considered statistically significant at $\mathrm{p}<0.05$.

\section{Results and discussion}

According to ultrasound data, 27 patients (74.80\%) exhibited type III AATSV and 9 patients (25.20\%) exhibited type IV AATSV. In 20 patients (55.40\%) AATSV was combined with varicotrombophlebitis (VTF) affecting lateral branches of the thigh and lower leg. In 27 patients (74.80\%) with AATSV, incompetent perforator veins were found on the crura.

Twenty-five patients (69.25\%) reported slight pain in the sites of postoperative wounds and at the site of EVEW treatment lasting for 2-5 days post-surgery. In 18 patients (49.86\%) a dense strand sensation along the GSV trunk was reported within 3 months after EVEW treatment. In 3 patients (8.31\%), decreased sensitivity was experienced in local areas that disappeared at 7 days after EVEW treatment. At days 2 and 7 after EVEW treatment, ultrasound of the GSV revealed 2-2.5-fold thickening of the vascular wall with respect to pre-surgery observations, as well as tight fixing of the hyperechogenic thrombotic masses to the vascular wall. The treated segments of the veins were not compressible, and no blood flow was observed by color duplex mapping. Free fluid was observed in the paravasal cellular tissue at day 2, likely caused by intraoperative use of tumescent anesthesia, but was absent at day 7. Three months after EVEW, complete occlusion of the thrombus vein was observed, as well as increased echogenicity in the lumen of the vessel. The paravasal tissue appeared normal. At 6 months post-surgery, the examination revealed more pronounced signs of vein occlusion relative to control than were observed at 3 months. Twelve months after EVEW treatment, connective tissue was detected at the site of the obliterated vein that alternated with segments of ablation.

At 12 months, 36 patients were examined. Two patients (5.54\%) had hemodynamically insignificant recanalization and one patient (2.77\%) exhibited complete recanalization of the GSV trunk. No deep vein thrombosis, recurrent superficial vein thrombosis or other specific complications were observed in any of the patients within the 12-month follow-up period.

Complete occlusion and fibrotic transformation of the thrombotic trunk of the GSV was achieved in 33 patients (91.41\%) at 12 months after EVEW treatment, which is comparable with the results of other authors regarding various endothermal treatments for chronic venous insufficiency.

All 36 patients returned completed CIVIQ questionnaires at each survey interval. For the purpose of dynamic assessment and validation of the effect of the independent variable in the survey, the initial level of the dependent variable was determined using the mean score of the QoL assessment (CIVIQ scale). At a certain interval in the post-operative observation period, the specified indicator was also calculated.

Wilcoxon T-test was used to determine the effectiveness of treatment for dependent samples with few compared pairs. The observation and comparison of patient outcomes highlighted a leading role of pain, social and psychological factors in QoL patients with AATSV, for whom a significant difference in the levels of the dependent variable before treatment and at each of the post-intervention examination points was determined $(\mathrm{p}<0.05)$.

The QoL score in patients with pain, social, and psychological factors after surgical treatment decreased 2.1fold in the survey 12 months post-surgery $(\mathrm{p}<0.05)$. Clinically, pain in the feet or lower legs appeared reduced, impairment on work activity, lifestyle and rest decreased, and patients spent more time on their feet than they reported doing before surgery. In addition, a positive physical effect of EVEW treatment was observed: at 12 months after surgical treatment, there was a significant correction of venous blood flow disorders. This appeared to contribute to a 50\% reduced average score on the CIVIQ scale compared with preoperative data $(\mathrm{p}<0.05)$. Patients reported improvements in stair climbing, squatting, walking, homework. Improvements in social functioning scores were also observed at the 12-month interval, with the QoL limitation of social indicators decreased 1.8-fold ( $\mathrm{p}<0.05)$. Thus, after surgical treatment, the QoL regarding social factor (being in public transport, a car, playing sports or exercising) has improved significantly.

Psychological indicators also showed improvement at 12 months post-surgery. Before surgery, patients experienced negative emotions and low esteem with respect to the appearance of their lower limbs and quickly tired of exercise. However, after surgical treatment, the QoL score representing psychological indicators improved 2.3-fold $(\mathrm{p}<0.05)$. 
Improvement was observed in patients in terms of several QoL indicators at defined time intervals within the observation period following EVEW treatment, as evaluated by the CIVIQ score (Figure 1).

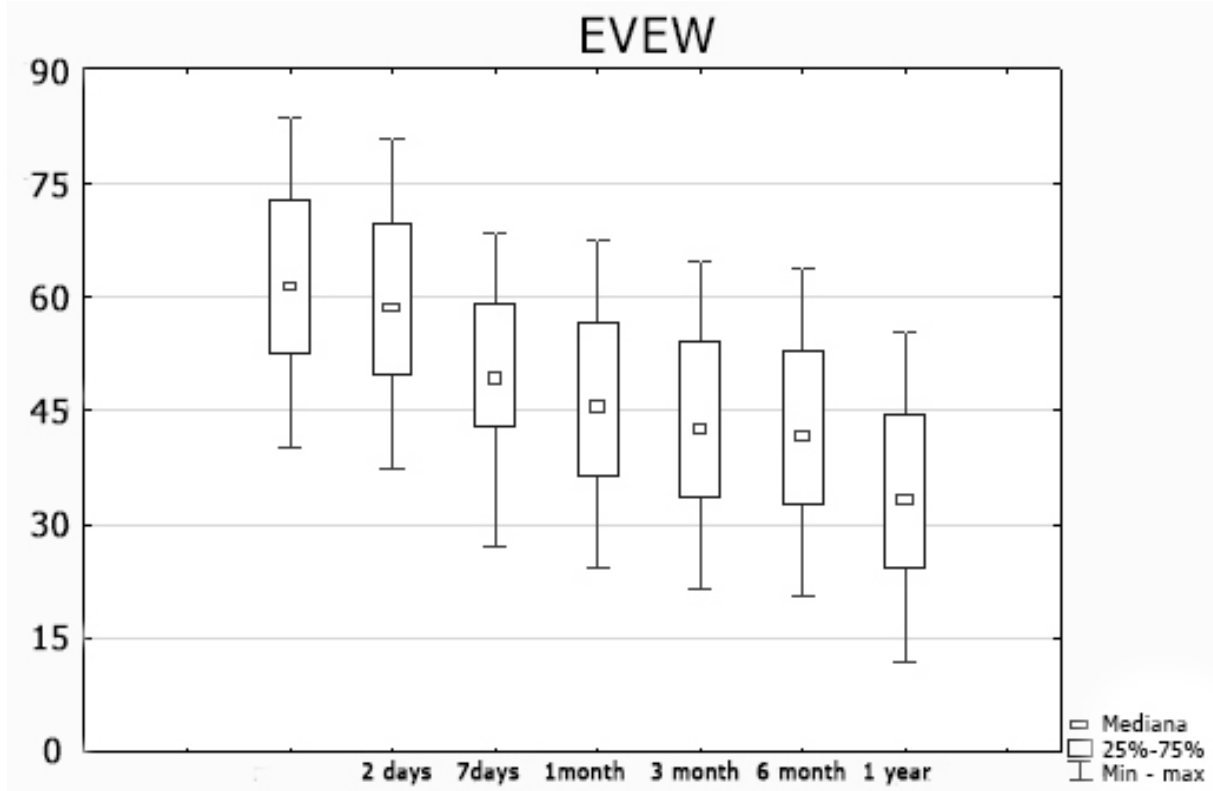

Figure 1. Dynamics of quality of life on a relative scale according to the CIVIQ-20 scale

The results obtained indicate a positive dynamic impact of EVEW on the QoL of patients treated for AATSV. A single instance of a perforated vein was observed within 12 months after treatment, which contributed to the recanalization of the infiltrated barrel of the GSV, but no correlation with the increase in CIVIQ score was observed in this case.

As may be expected, most guidelines advocate conservative treatment for AATSV, even in cases where the thrombus has progressed $2 \mathrm{~cm}$ along the common femoral vein, which is similar to the treatment strategy for patients with deep vein thrombosis (DVT). However, surgical treatment provides the exclusion of the damaged vein, which may cause recurring DVT, pulmonary embolism and superficial thrombophlebitis, from the circulation. During anticoagulation therapy, the affected vein remains in situ and the effect is mostly observed after several weeks of the treatment start. Further studies are needed to more comprehensively evaluate the benefits or superiority of a surgical approach for patient with AATSV, specifically of the GSV.

\section{Conclusions}

Endovenous electric welding of the thrombotic trunk of GSV is an effective, low-traumatic new surgical method for treatment of acute ascending thrombophlebitis. Within 12 months complete fibrotic transformation is achieved in the areas of ablation of the thrombus vein trunk in $91.41 \%$ of patients. According to the CIVIQ questionnaire, the QoL of patients before and after surgical treatment using EVEW significantly increases as evaluated according to 3 of the 4 QoL indicators (physical, social, psychological functioning). The presented data highlight the possibility of effective and safe widespread clinical use of the endovenous welding method for the treatment of acute ascending thrombophlebitis of the trunk of a GSV.

\section{References:}

1. Cosmi B. Management of superficial vein thrombosis. J Thromb Haemost. 2015; 13(7): 1175-1183. https://doi.org/10.1111/jth.12986

2. Giannoukas AD. Current management of superficial thrombophlebitis of the lower limb. Phlebolymphology. 2013; 20(3): 127-133.

3. Decousus H, Bertoletti L, Frappé P, Becker F, Jaouhari AE, Mismetti P, etal. Recent findings in the epidemiology, diagnosis and treatment of superficial-vein thrombosis. Thromb Res. 2011; 127(suppl 3): S81-S85. https://doi.org/10.1016/S0049-3848(11)70022-6 
4. Samuelson B, Go AS, Sung SH, Fan D, Fang MC. Initial management and outcomes after superficial thrombophlebitis: the Cardiovascular Research Network Venous Thromboembolism study. J Hosp Med. 2016; 11(6): 432-434. https://doi.org/10.1002/jhm.2553

5. Decousus H, Frappé P, Accassat S, Bertoletti L, Buchmuller A, Seffert B, et al. Epidemiology, diagnosis, treatment and management of superficial-vein thrombosis of the legs. Best Pract Res Clin Haematol. 2012; 25(3): 275-284. https://doi.org/10.1016/j.beha.2012.07.005

6. GilletJL. Management of superficial vein thrombosis of the lower limbs:update and current recommendations. Phlebolymphology. 2015; 22(2): 82-89.

7. Lozano FS, Almazan A. Low-molecular-weight heparin versus saphenofemoral disconnection for the treatment of above-knee greater saphenous thrombophlebitis: a prospective study. Vascular and Endovascular Surgery. 2003; 37(6): 415-420.

8. Belcaro G, Nicolaides AN, Errichi BM, Cesarone MR, Sanctis MT, Incandela L, et al. Superficial thrombophlebitis of the legs: a randomized, controlled, follow-up study. Angiology. 1999; 50(7): 523-529.

9. Di Nisio M, Wichers IM, Middeldorp S. Treatment for superficial thrombophlebitis of the leg. Cochrane Database of Systematic Reviews. 2018; 2: CD004982. https://doi.org/10.1002/14651858.CD004982.pub5

10. Marković MD, Lotina SI, Davidović LB, Vojnović BR, Kostić DM, Cinara IS, et al. [Acute superficial thrombophlebitis - modern diagnosis and therapy]. Srp Arh Celok Lek. 1997; 125(9-10): 261-269 (in Serbian).

11. Konstantynova HD, Zubarev AR, Hradusov EH. [Phlebology]. Moscow: Vydar Publishing House; 2010. p. 160 (in Russian).

12. De Maeseneer M. How to treat superficial thrombophlebitis?. Phlebolymphology. 2010; 17: 48-49.

13. Perrin M, Guex JJ, Gillet JL. [Surgical treatment of superficial venous thrombosis of the lower limbs]. Encycl. Med. Chir. Techniques chirurgicales - Chirurgie vasculaire. 2000; $43-165$ (in French).

14. Krause U, Kock HJ, Kröger K, Albrecht K, Rudofsky G. Prevetion of deep venous thrombosis associated with superficial trombophlebitis of the leg by early saphenous vein ligation. Vasa. 1998; 27(1): 34-38.

15. Savoliuk SI, Khodos VA, Herashchenko RA, Horbovets VS. First experience of endovenous welding use in the surgical treatment of acute ascending thrombophlebitis of the great saphenous vein. Khirurhiia Ukrainy. 2018. 67(3): 63-67 (in Ukrainian). https://doi.org/10.3978/SU2018-3-63

16. Patent of Ukraine No. 128122. [Method of surgical treatment of acute ascending thrombophlebitis of great saphenous vein]. 2018 Sep 10 (in Ukrainian).

17. Savolyuk SI, Khodos VA, Gerashchenko RA, Gorbovets VS. [Ultrasound changes in the thrombosed great saphenous vein before and after exposure to endovenous high frequency electric welding]. Bulletin of the Vinnitsa National Medical University. 2018; 22(3): 489-493 (in Ukrainian). https://doi.org/10.31393/reports-vnmedical-2018-22(3)-19

18. Launois R. Health-related quality-of-life scales specific for chronic venous disorders of the lower limbs. J Vasc Surg Venous Lymphat Disord. 2015; 3(2): 219-227. http://dx.doi.org/10.1016/j.jvsv.2014.08.005

19. Launois R, Reboul MJ, Henry B. Construction and validation of a quality of life questionnaire in chronic lower limb venous insufficiency (CIVIQ). Qual. Life Res. 1996; 5(6): 539-554. https://doi.org/10.1007/bf00439228

20. Bland JM, Dumville JC, Ashby RL, Gabe R, Stubbs N, Adderley U, et al. Validation of the VEINES-QOL quality of life instrument in venous leg ulcers: repeatability and validity study embedded in a randomised clinical trial. BMC Cardiovasc Disord. 2015 Aug 11; 15: 85. https://doi.org/10.1186/s12872-015-0080-7

21. Sinožić T, Baždarić K, Šverko D, Ružić A, Katić M. Validation of the Croatian version of CIVIQ quality of life questionnaire in patients with chronic venous disorders. Croat Med J. 2017; 58(4): $292-299$. https://doi.org/0.3325/cmj.2017.58.292 